\title{
A Mediating Role of Relational Psychological Contract on the Relationship Between Work Place Spirituality and Employee Turnover Intention in Nigeria Banks
}

\author{
Oyekunle Oyelakin ${ }^{1}$, Agu Godswill Agu ${ }^{2}$ \\ ${ }^{1}$ Department of Business Administration, Ahmadu Bello University, Zaria, Nigeria \\ ${ }^{2}$ Department of Marketing, Abia State University, Uturu, Nigeria
}

Email address:

oyekunleoyelakin@yahoo.com (O. Oyekunle), talk2godsag@yahoo.com (A. G. Agu)

\section{To cite this article:}

Oyekunle Oyelakin, Agu Godswill Agu. A Mediating Role of Relational Psychological Contract on the Relationship Between Work Place Spirituality and Employee Turnover Intention in Nigeria Banks. American Journal of Applied Psychology. Vol. 6, No. 4, 2017 , pp. 75-82. doi: 10.11648/j.ajap.20170604.15

Received: June 3, 2017; Accepted: June 28, 2017; Published: October 18, 2017

\begin{abstract}
The study examined the effect of workplace spirituality (meaningful work, inner life and community) on employee turnover intention in Nigeria banks mediated by relational psychological contract. Data were collected from a sample of 357 employees in 21 Deposit Money Banks located in Kaduna State. Structural Equation Model was used to explore the effect. Findings revealed that meaningful work has positive, significant effect on employee turnover intention while inner life and community were found to have insignificant effect on employee turnover intention. Relational psychological contract was found to have fully mediating effect between workplace spirituality (inner life, meaningful work and community) and employee turnover intention. The most explanatory variable of the study is the relationship that exists between meaningful work and relational psychological contract. The study recommends that management of Banks should attach more importance to meaningful work and relational psychological contract of employees to reduce employee turnover intention.
\end{abstract}

Keywords: Workplace Spirituality, Relational Psychological Contract, Employee Turnover Intention

\section{Introduction}

Human resources are one of the most important resources in Nigeria Banks and a major capital an organization cannot do without. In the current socio-economic environment of turbulent change and the increase in leadership crises in workplace, it is of importance to understand the relationships between employers and their employees [1]. Considering the competitive nature in Nigeria Banking Sector, human capital gives competitive advantage to an organization, which therefore necessitates the need and importance to retain valuable and productive employees. [2] argued that spiritual dimension of employee should be incorporated into the current motivational paradigm in order to understand the problems of underperformance and ineffectiveness which may lead to turnover intention.

Turnover intention is seen as the behavioral attitude of an employee who wishes or desires to withdraw his/her services from an organization [3]. Turnover intention is considered detrimental to the organization in terms of replacement cost and work disruption. An employee's decision to quit an organization for another is usually an undesirable outcome for the employer and the employee as it affects both of them [4]. Turnover rates in Nigeria Banks are critical managerial issue because of risks, financial costs, transaction costs and psychological costs to be incurred [5]. [4] emphasized that employee turnover affects organization as it increases direct costs such as cost of recruitment, selection and training of new employees. Indirect costs to be incurred include; knowledge lost and reduction in productivity as employee will leave a vacuum to be filled up by new recruited employee. Therefore it is imperative to determine the causes in order to avert the negative effect on the performance of an organization [6]. Turnover intention can be either voluntary or involuntary. Voluntary turnover is when an employee decides to leave the organization willingly, while involuntary turnover intention occurs when the organization is not satisfied with an employee's performance and makes decision to disengage the employee. 
Workplace spirituality was defined by [7] as a culture in which organizational values encourage a sense of purpose through meaningful work occurring within the context of the workplace community. Workplace spirituality brings about personal benefits derived from joy, satisfaction, and commitment, organizational benefit through increase in productivity, reduced absenteeism and also the rate of turnover [8]. According to [9] stated that organizations that embrace workplace spirituality tend to grow faster, have high rates of return, and increased efficiencies more than others. Religion is intertwined with spirituality. It can strengthen and regularize spirituality, therefore it can make spirituality firm, stable and appropriate [10]. Work place spirituality is a multidimensional construct. The present study focused on its three key dimensions as postulated by [11]. The three dimensions are inner life, meaningful work, and community.

\subsection{The Problem}

Best organizations practice are now keen in developing psychological contracts that are strictly relational, and which focus on employee development on a wider scope to include the spiritual needs of employees [12]. Psychological contract offers a framework for monitoring employee attitudes and priorities on proxies that can influence performance in a given organizational environment, which has relational psychological contract as one of its dimensions. Relational contract is that which constitutes the relationship between employee and the organization [13]. [14] are of the opinion that psychological concepts include; love, compassion, patience, tolerance, forgiveness, contentment, personal responsibility, and a sense of harmony with one's environment which this study termed to be characteristics of relational psychological contract. Relational psychological contract if not well managed may lead to the loss of employee's emotional attributes [15].

Given the pressure and fear on Nigerian Banks employees to retain their jobs, there seem to be issues surrounding the expected relational contract between the employees and their employers. This has left many of the employees in the recent time as job seekers. The Minister of Labour and Employment, Senator Chris Ngige, expressed shock at the rate at which employers in the financial sector especially banks sack their workers. The Federal Government, to this effect, issued directives on banks to stop further retrenchment, threatening to withdraw the operating license of any bank that breached the directives. The economic predicament of the country also contributed in the volume of staff retrenchment within the sector in the year 2016.

Studies conducted previously have shown varied results on the effect of workplace spirituality on turnover intention [16], [17], [18], [19], [20] and [21]. However, there are scanty studies on this area of business management in the Nigerian context and this study stands to fill the gap.

\subsection{Study Objectives}

This study aims at:
1). Examine the effect of workplace spirituality, proxied by meaningful work, inner life and community, on employee turnover intention in Nigeria Banks.

2). Determine the mediating role of relational psychological contract between workplace spirituality and employee turnover intention.

\section{Review of Related Literature}

\subsection{Conceptual Review}

\subsubsection{Turnover Intention}

Different definitions of turnover intention have been given by various authors. Most definitions are channeled towards the same area and have similar meanings. According to [22], turnover intention is the conscious, deliberate and willfulness of an employee to leave an organization. In other words, turnover intention, intention to quit or leave is define as the desire to withdraw one's services from an organization. Various reasons could be attached to turnover intention such as unfavorable working environment, pay reduction, psychological and social factors, health status, nature of job etc. Organizations suffer from employee turnover through loss of experienced workers and good customer relationship [23]. Also the cost of replacement of employee and training are direct costs that affect organizations, indirect costs are loss of social capital, low morale which can result in low productivity [24].

\subsubsection{Workplace Spirituality}

Although, many definitions have been offered to capture the essence of workplace spirituality, it seems that authors are not yet in full agreement on the conceptual definition of the construct [25]. Accordingly, workplace spirituality is defined as the recognition that employees have an inner life that nourishes and is nourished by meaningful work that takes place in the context of community [11]. Spirituality in the workplace is about people who perceive themselves as spirited beings, whose spirits desire and need to be energized through work. It is about experiencing real purpose and meaning at work beyond paychecks and performance reviews [26]. There are different dimensions postulated by different authors, but this study adopted the three dimensions of workplace spirituality which are inner life, meaningful work, and community proposed by [11].

Meaningful work is a fundamental aspect of workplace spirituality. It involves having a deep sense of meaning and purpose in one's work [27]. Meaningful work represents how employees interact with their day-to-day work at the individual level [28]. Providing a deeper sense of meaning and purpose for employees is important, as this enables employees to perform better and to be more productive and creative at work. This perspective contends that incorporating spirituality at work provides employees and managers a deeper sense of meaning and purpose at work [29].

Community involves having a connection or relationship with others which has been articulated as a sense of community [11]. Community perspective is centered on interpersonal relationships, collective dimensions, and social 
dynamics of spirituality. It contends that incorporating spirituality at work provides organizational members a sense of community and connectedness, and thus increases their attachment, loyalty, and belonging to the organization [29]. This dimension of workplace spirituality occurs at the group level of human behavior and concerns interactions between employees and their co-workers [28].

Inner life means the feelings individuals have about who they are, what they do and their contributions [30]. Spirituality is embedded in mankind and thus has become part of human nature. This concept can be seen in some while it is hidden in some and differs from one person to another [31]. Employees have spiritual needs which constitute their inner lives just as they have physical, cognitive and emotional needs [32]. A job is believed to be motivating when there is a distinct gap between the content of a job and the inner life of an employee [33].

\subsubsection{Relational Psychological Contract}

Relational contract is that which constitutes the relationship between employee and the organization [13]. It is developed on socio-emotional factors based on trust and organizational commitment [34]. Under a relational contract, employees offer loyalty and commitment to their organization in exchange for security of employment which is guaranteed by long-term contracts [35]. Relational contract includes loyalty, trust and mutual stability, employees are more willing to work, give help to co-workers and support organizational changes [36].

From these proxies, seven hypotheses were developed and tested in the study.

\subsection{Theoretical Framework}

Two theories were used to underpin this study. They are organisational support theory and Social exchange theory. The basic assumption of social exchange theory is that individuals establish and continue social relations on the basis of their expectations that such relations will be mutually advantageous. It was found in previous research that if the contract arrangement between employee and employer is being honoured employees will have a positive attitude toward performing a given task and reduced the intention to leave the organisation. Organizational support theory assumes that in order to meet holds that in order to meet socio-emotional needs and to assess the benefits of increased work effort, employees form a general perception concerning the extent to which the organization values their contributions and cares about their well-being. Employees who are cared for and valued by their organizations will be attached to their organization in affective way.

Consequently, the present study has adopted this theory to underpin its model as shown in figure 1.

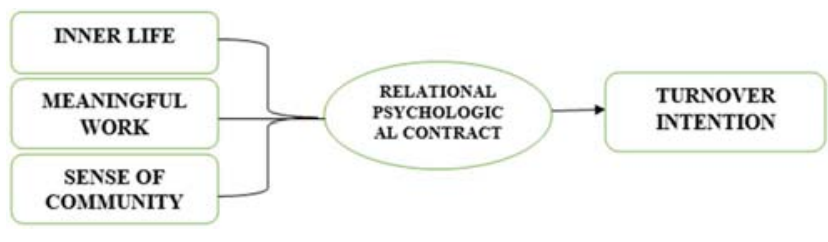

Figure 1. Model for the Study.

The model depicts a relationship amongst the key variables that affect employee turnover intention in Nigeria Banks. The framework is developed to test the effect workplace spirituality on employee turnover intention in Nigeria Bank: a role of relational psychological contract.

\subsection{Review of Empirical Literatures}

[37] examined the effects of workplace spirituality and work satisfaction on intention to leave an organization. A sample of seventy-one graduate students in the MBA program were administrated questionnaire. The study found that workplace spirituality significantly influenced the intention to leave as did work satisfaction. The sample size of the study is however small compared to the sample size of the current study. [38] assessed whether workplace spirituality program impacted on turnover intention in food service organizations. The sample consisted of 53 employees of a multi-location quick-service restaurant in Florida. Findings show that workplace spirituality program on turnover intention was not significant. However, the sample size of the study and the domain examined is different from the current study.

[21] investigated the influence of workplace spirituality on quality of patient-care delivered by medical professionals and turnover intention. A sample of 253 medical professionals in both public and private hospitals in north India was gathered for data collection. The finding demonstrated that workplace spirituality was a positive predictor of quality of patient care, and a negative predictor of turnover intention in both hospitals equally. Compared to other study reviewed for the study, the study has a larger sample size which is commendable. [20] examined the relationships between workplace spirituality, organizational commitment, and turnover intention by gathering data from 190 Starbucks supervisor in the southwest region of the U.S. Questionnaires were used for data collection. Structural Equation Modeling was used. Findings showed that supervisors' workplace spirituality had a significant negative effect on their intention to leave the current job. The study considered only supervisors, therefore result may be bias.

[15] explored the influence of psychological contract on turnover intention of employees, and the mediating mechanism of organizational commitment is tested. Questionnaire was administered on employees of high-tech enterprises in Xi'an City. The results show that transactional and the relational psychological contract has a significant impact on turnover intention while organizational commitment plays a fully mediating role in the relationship between transactional psychological contract and turnover 
intention, and plays a partial mediating role in the relationship between relational psychological contract and turnover intention. The study used a mediator which is commendable but the present study uses relational psychological contract as a mediator which the study use as a dependent variable.

[13] examined the relationship between psychological contract factors operationalized in terms of transactional, rational and balance psychological contracts and employee turnover intention in private sector organization in Nigeria. A structured questionnaire was used to ascertain the responses from 280 respondents Findings of the study indicated that transactional psychological contract has a strong positive significant relationship with turnover intention of employee in private organization in Nigeria. The relational and balance psychological contracts dimensions were significantly related to turnover intention to leave a private organization. [39] examined the relationship between psychological contract breach and fulfillment on employees' intention to quit. Data was collected from a sample of 300 employees in telecom sector of Rawalpindi/Islamabad, Pakistan. Correlation/Regression analysis was used to explore the relationships between psychological contract breach, fulfillment and employees' intention to quit. A positive relationship was found between psychological contract breach and intention to quit behavior of employees and a negative relationship between psychological contract fulfillment and intention to leave.

[12] examined the effect of Spirituality on the Psychological Contract: Towards the Relational. Propositions were developed to assert the need for more relational aspects of psychological contracts to bolster workplace spirituality, and ultimately, help satisfy the spiritual needs of employees.

In view of the empirical literature reviewed, it can be deduced that workplace spirituality dimensions (community, inner life and meaningful work) are possible variables that can influence employee turnover intention. Thus, this study used these variables to determine their influence on employee turnover intention, while relational psychological contract was used as a potential mediator.

\section{Research Methodology}

This study was conducted as a cross-sectional survey research, through questionnaire which is designed to obtain pertinent information concerning the current state of affairs. The population of the study consists of all employee of the 21 deposit money banks located in Kaduna State. A total of 357 respondents were used as the sample size. Data were analyzed using Partial Least Square (Smart PLS 3) and followed the two-stage approach for assessing the measurement model and the structural model respectively suggested by [40]. This study tested the important criteria and processes to estimate the outer and inner model. The questionnaire is a modified version of workplace spirituality developed by [11] which has, for community (7 items), meaning at work (6 items), and inner life (5 items). Adjusted versions quitting intention (3 items) developed by [41] were used for the measurement of intention to leave. The measurement of relational psychological contract (6 items) developed by [34] was used. The instrument was subjected to content validity based on the evaluation three research experts in the field of management. The questionnaire was subjected to reliability test using data collected from 20 samples of the respondents. The reliability of the responses on each variable was tested using the reliability scale of Cronbach's alpha. The alpha values for each variable is shown in table 1.

Table 1. Reliability Statistics.

\begin{tabular}{lll}
\hline Responses & No of items & Alpha \\
\hline Workplace Spirituality & 18 & 0.732 \\
Turnover Intention & 3 & 0.792 \\
Relative Psychological contract & 6 & 0.821 \\
\hline
\end{tabular}

All alpha reliabilities for all scales were greater than 0.7 , therefore, meeting acceptance standards for research as put forward [42].

\section{Data Analysis}

Table 2. Summary of Responses.

\begin{tabular}{lll}
\hline Items & No of Copies & Percentage \\
\hline No of Questionnaire Distributed & 357 & 100 \\
No of Returned Questionnaire & 341 & 94.7 \\
No of Useful Questionnaires & 322 & 89.4 \\
\hline
\end{tabular}

From table 2, the no of useful questionnaire is $322(89.4 \%)$ which is a response rate considered sufficient for statistical reliability and generalization [43].

Table 3. Descriptive Statistics.

\begin{tabular}{llll}
\hline Characteristics & Frequency & Percentage & $\begin{array}{l}\text { Cumulative } \\
\text { percentage }\end{array}$ \\
\hline Gender & & & \\
Male & 225 & 69.8 & 69.8 \\
Female & 97 & 30.2 & 100.0 \\
Age & & & \\
18-25 & 92 & 28.6 & 28.6 \\
26-35 & 84 & 26.0 & 54.6 \\
36-45 & 98 & 30.4 & 85.0 \\
46 and above & 48 & 15.0 & 100.0 \\
Educational Qual & & & \\
SSCE & 0 & 41.3 & 1.3 \\
OND/NCE & 89 & 27.6 & 28.9 \\
B. Sc & 184 & 57.1 & 86.0 \\
MSc./Ph. D & 45 & 14.0 & 100.0 \\
Management Level & & & 82.0 \\
Lower management & 174 & 54.0 & 100.0 \\
Middle management & 90 & 28.0 & \\
Top Management & 58 & 18.0 & \\
\hline
\end{tabular}

From table $3,69.8 \%$ of the respondents were males while 
$30.2 \%$ were Females. 28.6\% aged between $18-25$ years, $26 \%$ were between 26 - 35 years, $30.4 \%$ were of age $36-45$ years and $15 \%$ were of age 46 years and above. Again, $1.3 \%$ of the respondents had SSCE, 27.6\% had OND/NCE, 57.1\% had $\mathrm{B}$. Sc. and $14 \%$ had MSc./Ph. D. The management level of respondent shows that $54 \%$ of the respondents are of lower management, $28 \%$ belongs to the middle management while $18 \%$ are of the top management.

Table 4. Construct Reliability and Validity.

\begin{tabular}{llllll}
\hline Construct & Items & Loadings & AVE & CR & CA \\
\hline \multirow{3}{*}{ Meaningful } & MEN1 & 0.782 & & & \\
Work & MEN4 & 0.715 & \multirow{2}{*}{0.519} & 0.842 & 0.762 \\
& MEN5 & 0.732 & & & \\
& MEN6 & 0.795 & & & \\
Community & COM2 & 0.903 & & & \\
& COM3 & 0.893 & \multirow{2}{*}{0.786} & 0.936 & 0.910 \\
& COM4 & 0.910 & & & \\
COM5 & 0.839 & & & \\
Inner Life & INN2 & 0.868 & & & \\
& INN3 & 0.921 & \multirow{2}{*}{0.831} & 0.952 & 0.932 \\
& INN4 & 0.923 & & & \\
Relational & INN5 & 0.934 & & & \\
psychological & REL1 & 0.870 & & & \\
contract & REL2 & 0.872 & \multirow{2}{*}{0.689} & 0.898 & 0.847 \\
& REL4 & 0.865 & & & \\
Turnover & REL6 & 0.701 & & & \\
Intention & TUN1 & 0.874 & & & 0.811 \\
\hline
\end{tabular}

Loadings should not be below 0.7 [42]. On Table 4, items measuring meaningful work were reduced to four, two (MEN2 and MEN3) items were deleted as the loaded below 0.7 prerequisite. Items measuring community were also reduced to for due to the fact that it does not load well 3 items (COM1, COM6 and COM7) were deleted. Only one item is deleted from inner life (INN1). Two items were also deleted from relational psychological contract (REL1 and REL5). All items measuring turnover intention were retained as they loaded above 0.7 .

Table 5. Convergent and Divergent Validity.

\begin{tabular}{llll}
\hline Construct & $\begin{array}{l}\text { Cronbach's } \\
\text { Alpha }\end{array}$ & Composite Reliability & AVE \\
\hline Meaningful work & 0.775 & 0.843 & 0.573 \\
Inner Life & 0.932 & 0.952 & 0.831 \\
Community & 0.910 & 0.936 & 0.786 \\
Relational P. C & 0.847 & 0.898 & 0.689 \\
Turnover Intention & 0.811 & 0.888 & 0.727 \\
\hline
\end{tabular}

Table 5 presents Cronbach's Alpha coefficient, composite reliability and AVE of the constructs. All Cronbach's Alpha coefficient is greater than 0.7 . The constructs met the minimum benchmark for composite reliability, as all construct has a coefficient greater than 7 . All constructs met the minimum benchmark for AVE, as all the constructs has an AVE coefficient greater than 5. The results shows that convergent validity exist [43].

\begin{tabular}{lllll}
\hline & Community & Inner Life & Meaningful Work & Relational Turnover Psyc \\
\hline Community & 0.887 & & & \\
Inner life & 0.469 & 0.912 & & \\
Meaningful work & 0.482 & 0.789 & 0.957 & 0.830 \\
Relational Psychological & 0.385 & 0.532 & 0.806 & 0.803 \\
Turnover intention & 0.423 & 0.546 & 0.715 & 0.853 \\
\hline
\end{tabular}

Table 6 presents the result of discriminant validity. The number that are bolded represent the square root of AVE of each latent variable. The square roots of all the AVE are higher than their correlation with other latent variable. Taking into consideration put forward by Fornell-larcker discriminant validity criterion, the data shows discriminant validity [43].

\section{Bootstrapping Analysis for Direct Relationship}

Bootstrapping analysis is conducted to determine the direct effect of the dimensions of work place spirituality on employee turnover intention ignoring the controlling for relational psychological contract. Bootstrapping was done by using 5000 subsamples with 322 cases. The bootstrapping analysis is presented in figure 2 .

\section{Test of Hypotheses for Direct Relationships}

Before testing for the mediating effect of relational psychological contract on the relationship between workplace spirituality and turnover intention, it is important to determine the direct effect of workplace spirituality on turnover intention.

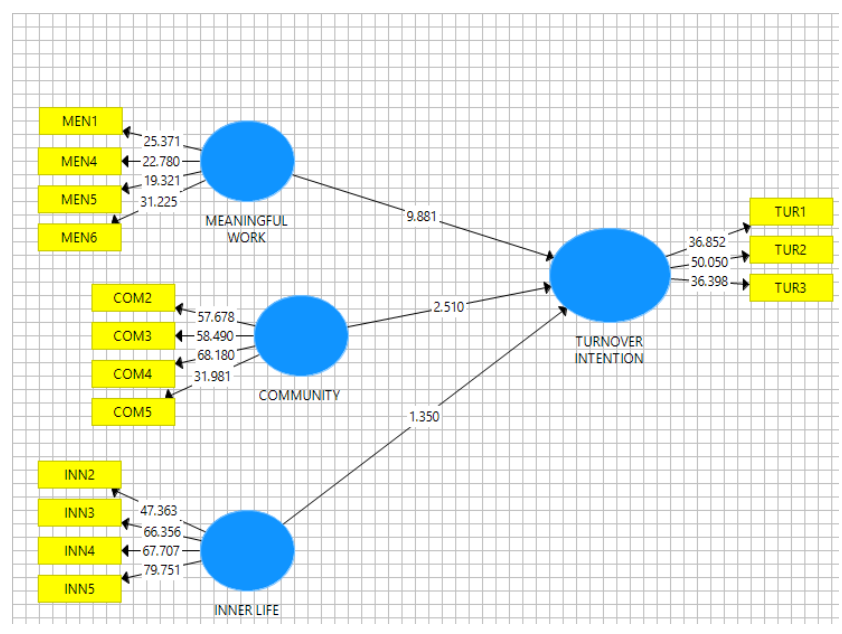

Figure 2. Structural model for direct relationship. 
Table 7. Direct Path Coefficient.

\begin{tabular}{llllll}
\hline Hypotheses & Beta Value & Standard Deviation & T Stat & P value & Decision \\
\hline Community -> Turnover intention & 0.029 & 0.048 & 0.618 & 0.268 & Accepted \\
Inner life -> Turnover intention & -0.062 & 0.071 & 0.871 & 0.192 & Accepted \\
Meaningful work -> Turnover & 0.740 & 0.082 & 8.997 & 0.000 & Rejected \\
intention & & &
\end{tabular}

From Table 7, it can be deduced that community has a positive effect but not significant on employee turnover intention at $\mathrm{P}$ value $0.268>.05$. As a result, the $\mathrm{H} 1$ that states that community does not have positive significant effect on turnover intention is accepted. Inner life has a negative effect and not significant on employee turnover intention at $P$ value $0.192>.05$. Thus, H2 that states that inner life does not have positive significant effect on turnover intention is accepted. Meaningful work has a positive and significant effect on employee turnover intention at $\mathrm{P}$ value $0.000<.01$. This implies that $\mathrm{H} 3$ that states meaningful work does not have positive significant effect on turnover intention is rejected.

The full structural model testing the mediating effect of relational psychological contract on both relationships (workplace spirituality and employee turnover intention) is presented in figure 3 .

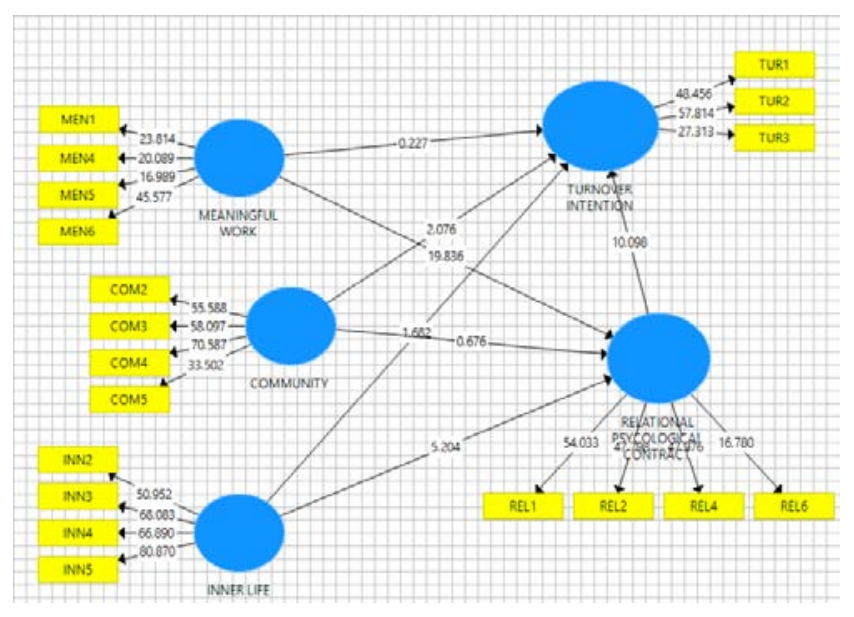

Figure 3. Full structural Model (direct and indirect).

Test of Hypotheses for Indirect Relationships

Table 8. Mediated Path Coefficient.

\begin{tabular}{llll}
\hline Relationship & Beta Value & T Statistics & P Value \\
\hline $\begin{array}{l}\text { Community -> Relational } \\
\text { Psychological contract }\end{array}$ & -0.091 & 2.026 & $0.021^{* *}$ \\
$\begin{array}{l}\text { Community -> Turnover } \\
\text { Intention }\end{array}$ & 0.097 & 1.916 & $0.028^{* *}$ \\
$\begin{array}{l}\text { Inner life -> Relational } \\
\text { Psychological Contract }\end{array}$ & -0.265 & 4.777 & $0.000^{*}$ \\
$\begin{array}{l}\text { Inner life -> Turnover } \\
\text { Intention }\end{array}$ & 0.141 & 2.068 & $0.019^{* *}$ \\
$\begin{array}{l}\text { Meaningful Work -> } \\
\text { Relational Psychological } \\
\text { contract }\end{array}$ & 1.054 & 18.782 & $0.000^{*}$ \\
$\begin{array}{l}\text { Meaningful work -> } \\
\text { Turnover intention } \\
\text { Relational Psychological } \\
\begin{array}{l}\text { ontract -> Turnover } \\
\text { Intention }\end{array}\end{array}$ & -0.021 & 0.191 & 0.424 \\
\hline
\end{tabular}

When controlling for the effect of relational psychological contract on turnover intention, the effect of the work meaningful life on employee turnover intention should either be no longer significant and/or a reduction in beta coefficient while the effect of inner life and community should be significant. This will signal the presence of mediation. On Table 8 , it is seen that with of relational psychological contract included in the model, community became significant on employee turnover intention, also the beta coefficient increase from .029 to .097. Likewise for inner life, where it became significant on employee turnover intention and the beta coefficient also increase from -0.062 to 0.141 . Meaningful work was no longer significant on employee turnover intention and the beta coefficient also reduced from 0.740 to -0.021 . This clearly shows that relational psychological contract mediates the relationships between community, inner life and meaningful work on employee turnover intention.

Furthermore, community has a negative significant effect on relational psychological contract at $p<.05$. On the other hand, inner life also has a negative significant effect on relational psychological contract at $\mathrm{p}<.01$. Also meaningful work has a positive significant effect on relational psychological contract at $\mathrm{p}<.01$. Lastly relational psychological contract has a positive significant effect on employee turnover intention.

Thus, H4: that states that relational psychological contract does not mediate the relationship between community and employee turnover intention is rejected. H5: that states that relational psychological contract does not mediate the relationship between inner life and employee turnover intention is rejected. Likewise, H6: that states that relational psychological contract does not mediate the relationship between meaningful work and employee turnover intention is rejected.

Lastly H7: that states that relational psychological contract does not have positive significant effect on turnover intention is hereby rejected.

Table 9. $R$ Square.

\begin{tabular}{lll}
\hline Construct & R Square & Adjusted R Square \\
\hline Relational psychological contract & 0.659 & 0.656 \\
Turnover Intention & 0.671 & 0.667 \\
\hline
\end{tabular}

Table shows the R2 of 0.659 and 0.671 is determined to be substantial by literatures. Relational psychological contract and turnover intention have an adjusted R2 value of 0.656 and 0.667 respectively. This means that community. Inner life and meaningful work account for $65 \%$ change in relational psychological contract, while relational psychological 
contract on the other hand account for $66 \%$ change on employee turnover intention. $35 \%$ and $34 \%$ change in relational psychological contract and turnover intention respectively is accounted for by other variables not incorporated in the model.

Table 10. Effect Size of Exogenous and Endogenous Variables.

\begin{tabular}{ll}
\hline Construct F Square & Effect Size \\
\hline Community -> Relational Psychological contract & 0.016 Small effect \\
Community -> Turnover Intention & 0.019 Small effect \\
Inner life -> Relational Psychological contract & 0.075 Small effect \\
Inner life -> turnover Intention & 0.021 Small effect \\
Meaningful work -> Relational Psychological & 1.032 large effect \\
contract & 0.000 No effect \\
Meaningful work -> Turnover intention & 0.518 Large effect \\
$\begin{array}{l}\text { Relational Psychological Contract -> turnover } \\
\text { intention }\end{array}$ & \\
\hline
\end{tabular}

Table 10 show the effect size of each of the exogenous and endogenous variables in the study. The effect of community on relational psychological contract is 0.016 thus, the effect is small. The effect of community on employee turnover intention is 0.019. Inner life on relational psychological contract is estimated at 0.075 . Inner life on employee turnover intention has 0.021 . Meaningful work has the highest effect of 1.032 on relational psychological contract, while meaningful work has no effect on employee turnover intention. Relational psychological contract has 0.518 effect on turnover intention.

\section{Conclusion and Recommendations}

The results of this study bring some practical implication, especially for Banks. First, creating the atmosphere of spirituality in the workplace and having employee's positive attitude to work are critical to encourage employees to stay in an organization. Relational psychological contract is also very important to reduce employee turnover intention.

It can be deduced that community has a positive effect but not significant on employee turnover intention. Inner life has a negative effect and not significant on employee turnover intention. Meaningful work was found to have a positive and significant effect on employee turnover intention. Therefore Banks are encouraged to focus and give adequate attention to employee meaningful work as it was found to be highly significant on employee turnover intention.

Also in the study, relational psychological contract was found to fully mediate the effect of workplace spirituality and employee turnover intention. It means that encouraging relational psychological contract by having a good relationship with people, associated with work, and having similar value with the organization, may reduce employee turnover intention.

Prior to the findings of the study, the following recommendations were made;

1. Bank management should improve on employee meaningful work i.e. how employees interact with their day-to-day work at the individual work level in order to reduce voluntary employee turnover.

2. The working environment of Banks should promote social interactions and a sense of harmony among employees. Employee should be encouraged to portrait attributes such as love, compassion, patience, tolerance, forgiveness, contentment, personal responsibility.

3. Government should also enact and implement policy/legislation that will resist employers of bank from sacking employees without following due process.

The study recommends that organizations should transform from transactional psychological contracts to more relational and spiritual psychological contracts.

\section{Contribution to Knowledge}

The major theoretical contribution of this study is the inclusion of a mediator in the model. Most previous related studies studied the direct relation between workplace spirituality and employee turnover intention. Literatures that have considered introducing a mediator in the model have mostly used organization commitment, organizational identification and organizational support as the mediating variables. In addition, this study has provided an empirically based direction for banks on how to end the current massive employee retrenchment.

\section{References}

[1] Grobler, A. and Nicolaides, (2014). A critique of the psychological contract and spirituality in the South African workplace viewed in the light of Utilitarianism and Deontology, 3(1).

[2] Naidoo, M., (2014). The potential of spiritual leadership in workplace spirituality, Koers - Bulletin for Christian Scholarship 79(2), Art. \#2124, 8 pages. http:// dx.doi.org/10.4102/koers. v79i2.2124.

[3] Aydogdu, S. \& Asikgil, B. (2011), An empirical study of the relationship among job satisfaction, organizational commitment and turnover intention"e, International Review of Management and Marketing, vol. 1, no. 3, pp. 43-53.

[4] Ongoni, H. (2007) A review of the literature on employee turnover. African Journal of Business Management pp. 049 - 054 .

[5] Ozdevecioglu, M., Demirtas, O. and Kurt, T. (2015). The Effect of Leader-Member Exchange on Turnover Intention and Organizational Citizenship Behavior: The Mediating Role of Meaningful Work, Proceedings of the international management conference, 9, (1), 710-719.

[6] Rahman, W. \& Nas Z. (2013) "Employee development and turnover intention: theory validation", European Journal of Training and Development, Vol. 37 Issue: 6, pp. 564-579, doi: 10.1108/EJTD-May-2012-0015.

[7] Giacalone, R. A., \& Jurkiewicz, C. L. (n.d.). Handbook of Workplace Spirituality and Organizational Performance.

[8] Fry, L. W. (2003). Toward a theory of spiritual leadership. The leadership quarterly, 14(6), 693- 727.

[9] Jurkiewicz, C. L. \& Giacalone, R. A. (2004). A Values Framework for Measuring the Impact of Workplace Spirituality on Organizational Performance. Journal of Business Ethics, 49(2), 129-142. doi: 10.2307/25123159. 
[10] Salarzehy $\mathrm{H}$ et al., (2011). Use of OCB found to increase organizational spirituality, there is a significant relationship between OCB and its dimensions, and organizational spirituality.

[11] Ashmos, D., \& Duchon, D. (2000). Spirituality at work: conceptualization and measure. Journal of Management Inquiry, 9(2), 134-145.

[12] Moore, T. W. (n.d.). Individual Differences and Workplace Spirituality: The Homogenization of the Corporate Culture, 79-93.

[13] Umar, S and Ringim, J. (2015). Psychological Contract and Employee Turnover Intention among Nigerian Employees in Private Organizations, 219-229.

[14] Fry, L. W., \& Matherly, L. L. (1901). Spiritual Leadership and Organizational Performance: An Exploratory Study Spiritual Leadership and Organizational Performance : An Exploratory Study.

[15] Wang, Y., Li, Z., Wang, Y., \& Gao, F. (2017). Psychological Contract and Turnover Intention: The Mediating Role of Organizational Commitment, 21-35. http://doi.org/10.4236/jhrss.2017.51003.

[16] Chawla, V., \& Guda, S. (2012). Workplace Spirituality as a Precursor to Relationship-Oriented Selling Characteristics. $\mathrm{http} / / /$ doi.org/10.1007/s10551-012-1370-y

[17] Crawford, A., Hubbard, S., Lonis-Shumate, S., \& O' Neill, M., (2009). Workplace spirituality and employee attitudes within the lodging environment. Journal of Human Resources in Hospitality and Tourism, 8, 64-81.

[18] Charoensukmongkol, P., Daniel, J. S., \& Chatelain-Jardon, R. (2013). Enhancing workplace spirituality through emotional intelligence. The Journal of Applied Management and Entrepreneurship, 18(4), 3-17.

[19] Beehner, C. G. \& Blackwell, M. J. (2016). The impact of workplace spirituality on food service worker turnover intention. Journal of Management, Spirituality \& Religion Vol. 13, Iss. 4.

[20] Gatling, A., Kim, J., \&, Milliman, J. (2014). Workplace spirituality enables strong organizational commitment leading to decreased turnover intention in Starbucks supervisors.

[21] Munda, S. S. (2015). Workplace spirituality: Rekindling the humanitarian climate to improve organizational outcome. Proceeding of Twelfth AIMS International Conference on Management.

[22] Matz, A. K., Woo. Y, \& Kim, B.(2014). 'A Meta-Analysis of the Correlates of Turnover Intent in Criminal Justice Organizations: does agency type matter?' Journal of Criminal Justice 42: 233-243.

[23] Aladwan, K., Bhanugopan, R., \& Fish, A. (2012). Why do employees jump ship? Examining intent to quit employment in a non- western cultural context. Employee Relations, 35 (4), 408-422.

[24] Griffin, R. W. \& Moorhead, G. (2011). Organizational Behaviour, Cengage Learning, New York, NY.

[25] Walt, F., \& Klerk, J. (n.d.). Workplace spirituality and job satisfaction, 1-11.

[26] Marschke, E., Preziosi, R., \& Harrington, W. (2009). Spirituality in the Workplace, 7(8), 33-48.
[27] Milliman, J., Czaplewski, A. J., \& Ferguson, J. (2000). Workplace spirituality and employee work attitudes. An exploratory empirical assessment. http://doi.org/10.1108/09534810310484172.

[28] Wainaina, L., \& Iravo, M. (2014). Workplace Spirituality as a Determinant of Organizational Commitment amongst Academic Staff in the Private and Public Universities in Kenya, 4(12), 280-293. http://doi.org/10.6007/IJARBSS/v4i12/1362

[29] Karakas, F. (2010). Spirituality and Performance in Organizations: A Literature Review, 89-106. http://doi.org/10.1007/s10551-009-0251-5

[30] Vaill, P. B. (1998). Spirited leading and learning: Process wisdom for a new age. San Francisco: Jossey-Bass

[31] Javanmard, H. (2012). The impact of spirituality on work performance, 5(1), 1961-1966.

[32] Singh, J., \& Chopra, V. G. (2016). Relationship among Workplace Spirituality, Work Engagement and Grit, 18(11), 21-27. http://doi.org/10.9790/487X-1811032127

[33] Shamir, B. (1991). Meaning, self and motivation in organization. Organization Studies, 12(3), 405-424

[34] Rousseau, D. M. (1990). New hire perceptions of their own and their employer's obligations: A study of psychological contracts, Journal of Organizational Behavior, Volume 11, Issue 5, pages 389-400.

[35] Pawelczyk. (n.d.). Impact and Effects of Relational and Transactional Psychological Contract., 41-43

[36] Lee, H.-W. \& Liu, C.-H. (2009). The Relationship among Achievement Motivation, Psychological Contract and Work Attitudes. Social Behavior and Personality, 37, 321-328. http://dx.doi.org/10.2224/sbp.2009.37.3.321.

[37] Promsri, C. (2016). The effects of workplace spirituality and work satisfaction on intention to leave, 7(4), 90-94.

[38] Paracha, A. (2014). Impact of Psychological Contract Breach and Psychological Contract Fulfillment on Employees ' Intention to Quit In Telecom Sector of Pakistan, 16(1), 93-97.

[39] Urbach, N. \& Ahlemann, F. (2010). Structural equation modeling in information systems research using partial least squares. Journal of Information Technology and Theory 11(2): 5-36.

[40] Babin, B. J., \& Boles, J. S. (1998). Employee behavior in a service environment: a model and test of potential differences between men and women. Journal of Marketing, 62(2), 77-91.

[41] Hair, J., Black, W., Babin, B., \& Anderson, R. (2014). Multivariate Data Analysis. 7th ed. Pearson New International Edition: UK

[42] Aminu, M. I., (2015). Relationships between Organizational Memory, Intellectual Capital, Entrepreneurial Orientation, Dynamic Capabilities and Firm Performance in Nigeria. Doctoral Thesis, University Utara, Malaysia

[43] Garson, D. (2016). Partial Least Squares: Regression \& Structural Equation Models. USA: Statistical Associates Publishing. 